\title{
Eimeria species in young and adult sheep raised under intensive and / or semi-intensive systems of a herd from Umuarama city, Parana State, Brazil
}

Espécies de Eimeria em ovinos jovens e adultos criados em sistema intensivo e / ou semi - intensivo de um rebanho da cidade de Umuarama, Estado do Paraná, Brasil

\author{
Welber Daniel Zanetti Lopes ${ }^{\mathrm{I}}$ Fernando de Almeida Borges $^{\mathrm{II}}$ Thais de Paula Faiolla ${ }^{\mathrm{I}}$ \\ Liliane Tada Antunes ${ }^{\mathrm{I}}$ Dyego Gonçalves Lino Borges ${ }^{\mathrm{II}}$ Fernando de Souza Rodriguez ${ }^{\mathrm{II}}$ \\ Gisela Ferraro $^{\mathrm{I}}$ Weslen Fabricio Teixeira ${ }^{\mathrm{III}}$ Willian Giquelin Maciel ${ }^{\mathrm{II}}$ \\ Gustavo Felippelli ${ }^{\mathrm{II}}$ Alvimar José da Costa ${ }^{\mathrm{III}}$ Valdomiro Pereira ${ }^{\mathrm{I}}$ \\ Antônio Campanha Martinez
}

\section{ABSTRACT}

The present study aimed to identify Eimeria species in young and adult sheep raised under intensive and / or semiintensive systems of a herd from Umuarama city, Parana State, Brazil using the traditional diagnostic methods and to correlate the infection level/types of infection in the different age/system in this herd. Fecal samples were collected from the rectum of 210 sheep and were subjected to laboratory analysis to differentiate the species. Furthermore, animals were observed to determine the occurrences of the clinical or subclinical forms of eimeriosis. Out of the 210 collected fecal samples, 147 (70\%) were positive for Eimeria oocysts, and 101 (47.86\%) belonged to young animals that were raised under intensive and / or semi-intensive farming systems. Oocysts from 9 species of Eimeria parasites were identified in the sheep at the following prevalence rates: $\boldsymbol{E}$. crandallis, $50.0 \%$; E. parva, 21.6\%; E. faurei, 8.1\%; E. ahsata, 8.1\%; E. intricata, $5.4 \%$; E. granulosa, $2.7 \%$; E. ovinoidalis, $2.0 \%$; E. ovina, $1.3 \%$; and $\boldsymbol{E}$. bakuensis, $0.6 \%$. There were no differences regarding the more frequent Eimeria species among the different ages of animals or between the different farming management systems. Based on these data, $\boldsymbol{E}$. crandallis was the most prevalent, followed by $\boldsymbol{E}$. parva and $\boldsymbol{E}$. faurei species, regardless of the age. Higher parasitism was diagnosed in the young animals that were raised in a confinement regime, and the disease found in the herd was classified as subclinical. Further studies should be conducted in this herd, to verify if the eimeriosis subclinical can cause damage especially in young animals with a high level of infection.

Key words: coccidia, eimeriosis, ooPG, sheep.

RESUMO

O presente trabalho teve como objetivo realizar a identificação das espécies de Eimeria em ovinos jovens e adultos, criados em sistema intensivo e/ou semi-intensivo, de um rebanho da cidade de Umuarama, estado do Paraná, Brasil, utilizando-se métodos tradicionais de diagnóstico, bem como correlacionando o grau de infecção/tipo de infecção nas diferentes categorias animal presentes no rebanho. Amostras de fezes de 210 ovinos foram colhidas diretamente da ampola retal desses animais. Em seguida, procedeu-se à diferenciação das espécies em laboratório. Além disso, os animais foram observados, diariamente, durante o período de 20 dias, após a colheita de fezes, a fim de se evidenciar se a eimeriose ocorreu de forma clínica ou subclínica nos rebanhos. Das 210 amostras de fezes colhidas, 147 (70\%) foram positivas para oocistos de Eimeria. Dentre as 210 amostras, 101 (47,8\%) pertenciam aos animais jovens criados no sistema intensivo e/ ou semi-intensivo. Foram identificados oocistos de nove espécies de Eimeria parasitas de ovinos, com a seguinte prevalência: $\boldsymbol{E}$. crandallis (50,0\%), E. parva (21,6\%), E. faurei (8,1\%), E. ahsata (8,1\%), E. intrincata (5,4\%), E. granulosa (2,7\%), E. ovinoidalis (2,0\%), E. ovina $(1,3 \%)$ e E. bakuensis $(0,7 \%)$. Não houve diferença quanto às espécies de Eimeria mais frequentes, entre as diferentes idades dos animais e também entre os diferentes regimes de criação (manejo). Diante do exposto, $\boldsymbol{E}$. crandallis foi a espécies mais prevalente, seguida da $\mathbf{E}$. parva e E. faurei, independente da idade dos animais. Maior nível de parasitismo foi encontrado nos animais jovens criados em regime de confinamento, e a enfermidade foi classificada como eimeriose subclínica, independente da idade dos animais. Futuros estudos deverão ser conduzidos neste rebanho, a fim de evidenciar se a eimeriose subclínica desencadeia danos aos animais, especialmente nos jovens criados em confinamento.

Palavras-chave: coccídeos, eimeriose, OoPG, ovinos.

\section{INTRODUCTION}

Sheep eimeriosis is an infectious disease caused by protozoa of the genus Eimeria. It is a

IDepartamento de Medicina Veterinária, Universidade Estadual de Maringá (UEM), Campus Regional de Umuarama, 87020-900, Umuarama, PR, Brasil. E-mail: wdzlopes@hotmail.com. *Autor para correspondência.

${ }^{I}$ Departamento de Medicina Veterinária, Universidade Federal do Mato Grosso do Sul (UFMS), Campo Grande, MS, Brasil.

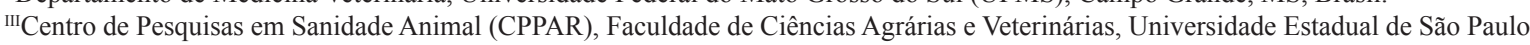
(UNESP), Jaboticabal, SP, Brasil. 
parasitic disease that is distributed worldwide and primarily affects young sheep that are raised under various management systems. However, Eimeria infections are more severe and more frequent in animals that are raised in intensive systems, which underscore the importance of such infections in confined herds (MENEZES et al., 2001). Eimeriosis is the name of the disease that is responsible for major losses of the producers of small ruminants, due to mortality and primarily to the poor performance of subclinically infected animals (CAVALCANTE et al., 2012).

Infection of animals occurs after the ingestion of these oocysts along with water and / or food contaminated with fecal matter (SILVA et al., 2007). In lambs reared in confinement, the ingestion of oocysts attached to the mother's teats, soil or bedding, ingestion by licking their own hair or even ingestion through contact with oocyst-contaminated feeders can be of high significance in disease transmission (HELLE, 1971; POUT, 1976). Immunity to different species of Eimeria is specific but not absolute, and clinical signs in animals may recur in a manner that depends mainly on the farming system and / or the immune status of each animal (LIMA, 2004).

Although this disease is common in sheep, there are few studies that report the specific frequencies of this parasite in livestock raised under intensive and / or semi-intensive systems in Brazil. Furthermore, although sheep can be heavily colonized by various species of Eimeria, not all of these species cause overt clinical disease and economic losses in the herd, which necessitates the specific identification of this agent in animals (CAVALCANTE et al., 2009). In this context, the present study aimed to identify Eimeria species in young and adult sheep raised under intensive and / or semi-intensive systems by traditional diagnostic methods and to correlate the infection level/types of infection in the different age/ system in this herd.

\section{MATERIAL AND METHODS}

Location and animals

The study was conducted in the sheep sector of the experimental farm of the Universidade Estadual de Maringá, Umuarama Campus, in the northwest region of Paraná state. The climate of the city is subtropical humid mesothermal. Summer is hot with high temperatures $\left( \pm 40^{\circ} \mathrm{C}\right)$ and winter frosts occur with some frequency. In this sector, animals are raised on a pasture (semi-intensive) or in a confinement regimen (intensive). A total of 130 male and female sheep (Texel and Santa Inês) between 2 and 36 months of age were raised on a pasture. Animals raised on pasture were arranged in an area of approximately 4 hectares and are fed on grass, mineral salt and water ad libitum. In addition to these animals, 80 sheep (Texel and Santa Inês) between 60 and 80 days of age were raised in a confinement regime and received roughage, mineral salt / water ad libitum and concentrate in their diet, which in this case comprised an intensive farming system. These 80 animals that were raised in a confinement regime were kept in a single stall $\left(70 \mathrm{~m}^{2}\right)$ with wood shavings for bedding. None of the animals had received any specific treatment against Eimeria.

Feces sample collection, animal observation and sample processing/identification of oocysts

During the March of 2012, fecal samples were harvested just once directly from the rectum of 210 sheep with the aid of a plastic bag that contained the identification information for each sheep. All the animals received triclorfon oral solution, against gastrointestinal nematode, 21 days before the beginning of the study. Out these 210 samples, 80 were owned by lambs raised in confinement system, 21 young animals raised in semi-intensive and 109 adult sheep raised under semi-intensive system. All theses 210 fecal samples were classified into 2 groups: young animals from 60 days to 8 months of age (101 samples) and adult animals of 8 or more months of age (109 sample), according to the criteria established by CAVALCANTE et al. (2012). Additionally, all sheep were observed daily for 20 days after the fecal collection to monitor occurrences of clinical or subclinical eimeriosis in the flock.

Initially, samples were processed by the centrifugal flotation method with a sugar solution (UENO \& GONÇALVES, 1998), than submitted to stimulate sporulation in solution of $2.5 \%$ potassium dichromate $\left(\mathrm{K}_{2} \mathrm{Cr}_{2} \mathrm{O}_{7}\right)$. For specific identification, one hundred oocysts of each species were measured with a Leica LAS light microscope coupled to a computer system. Species differentiation was performed according to shape, color, presence or absence of micropyle and micropilar cap, oocyst size, and morphological characteristics of sporocysts following the criteria established by VERCRUYSSE (1982), AMARANTE \& BARBOSA (1992), SOMMER et al. (1998), and DAUGSCHIES \& NAJDROWSKI, (2005).

Additionally, samples that were diagnosed as positive for Eimeria oocysts by the flotation technique were subjected to quantification by OoPG 
(oocyst count per gram of feces), using a modification of the technique described by GORDON \& WHITLOCK (1939).

Data analysis

Prior to statistical analysis, the data were evaluated to test the normality using the ShapiroWilk. The results of these tests directed for performing a non-parametric statistical analysis $(\mathrm{P}<0.05)$. Statistical analysis was performed using Graphpad Prism ${ }^{\circledR}$, v.5.03 (2009) [GraphPad Software ${ }^{\circ}$, USA], assuming a significance level of $5 \%$. The association between the regime and the level of infection of Eimeria was performed using the chi-square test. To compare the three regimes creation, data were subjected to nonparametric analysis of variance by the Kruskal-Wallis and as significant difference was found and the Dunn test for multiple comparisons was performed.

\section{RESULTS}

Out of the 210 collected fecal specimens, $147(70 \%)$ were positive for Eimeria oocysts. Among the 210 samples, $101(47.8 \%)$ were collected from young animals that were raised under the intensive and / or semi-intensive systems (Table 1). If only the young sheep were considered, regardless of whether they were raised under the intensive or semi-intensive system, all 101 samples $(100 \%)$ were positive for Eimeria oocysts. However, there were statistical differences $(\mathrm{P} \leq 0.05)$ in the infection level of animals that were raised under different farming systems (Table 1). The highest rates $(\mathrm{P} \leq 0.05)$ of Eimeria were found in young animals that were raised under the intensive system, and in these animals, the mean infection level was 4,830.1 oocysts per gram of feces (OoPG) per animal, compared to 333.3 OPG/animal in animals that were raised under the semi-intensive system (Table 1$)$. The lowest infection $(\mathrm{P} \leq 0.05)$ level were observed in adult animals that were raised under the semi-intensive system. In this case, the mean OPG of the animals was 87.2. Of the 109 fecal samples from adult sheep, only 47 (43.1\%) were positive for Eimeria oocysts (Table 1).

Table 2 shows that most of the young animals that were raised under the intensive system exhibited parasitism levels of approximately 5.050 to 10.000 OPG, which was classified as high parasitism. In young animals that were raised under the semiintensive system, a greater number of animals displayed OPG of 50 to 400 because no animals in this category presented negative tests for Eimeria oocysts. The 41 (of 47) adult animals that were raised under the semi-intensive system and were diagnosed as positive for Eimeria had a maximum infection level of 400 OPG. The 6 remaining animals had infection levels of 450-800 OPG/ animal.

Oocysts from 9 species of Eimeria parasites were identified in the sheep (Table 3) with the following prevalence rates: $\boldsymbol{E}$. crandallis $(54,7 \%), \boldsymbol{E}$. parva $(27,7 \%), \boldsymbol{E}$. faurei $(10,1 \%), \boldsymbol{E}$. ahsata $(9,4 \%)$, E. intrincata $(6,7 \%)$, E. granulosa $(3,4 \%)$, E. ovina $(2,7 \%)$, E. ovinoidalis $(2,0 \%)$, and E. bakuensis (0,7\%).

E. crandallis was the most prevalent in both young and adult sheep, regardless of the farming system, followed by $\boldsymbol{E}$. parva, E. faurei e E. ahsata. E. ovina, E. ovinoidalis e E. bakuensis displayed low prevalence rates in both young and adult animals (Table 3).

It is worth noting that during the 20 days of daily observations after fecal collection, the animals showed no clinical signs of eimeriosis, although some lambs reared in intensive system were found to have considerably high infection level. As there were no clinical cases of eimeriosis, the disease found in the herd was classified as subclinical.

\section{DISCUSSION}

Altogether, 9 species of Eimeria were identified in the present study. Studies conducted in Brazil by SILVA et al. (1988), AMARANTE \&

Table 1 - Proportion of sheep infected with Eimeria oocysts according to animal categories and farming systems.

\begin{tabular}{lcc}
\hline Category (Regime of raised) & Mean value of Eimeria oocysts per gram of feces & Total infected (\%) \\
\hline Young (intensive) & $4830,1^{\mathrm{A}}$ & $80(100 \%)$ \\
Young (semi-intensive) & $333,3^{\mathrm{B}}$ & $21(100 \%)$ \\
Adult (semi-intensive) & $87,3^{\mathrm{C}}$ & $47(43,1 \%)$ \\
P value & $<0.0001$ & - \\
\hline
\end{tabular}

1: Mean value of Eimeria oocysts per gram of feces followed by the same letter in the column do not differ $(\mathrm{P}>0.05)$. 
Table 2 - Intensities of Eimeria infection, based on the number of oocysts per gram of feces (OPG), in young and adult sheep raised under different farming systems.

\begin{tabular}{llll}
\hline OoPG & Young (intensive system) & Young (semi-intensive system) & Adult (semi-intensive system) \\
\hline $0-200$ & & & 10 \\
$250-400$ & 2 & 4 & 76 \\
$450-800$ & 17 & 5 & 6 \\
$450-800$ & 17 & 5 & 6 \\
$850-1000$ & 1 & 2 & 0 \\
$1050-3000$ & 16 & 0 & 0 \\
$3050-5000$ & 18 & 0 & 0 \\
$5050-10000$ & 21 & 0 & 0 \\
$1050-15000$ & 0 & 0 & 0 \\
$15050-20000$ & 0 & 0 & 0 \\
$2050-30000$ & 5 & 0 & 109 \\
Total & 80 & 21 & \\
\hline
\end{tabular}

BARBOSA (1992), VIEIRA et al. (1999) and SILVA et al. (2007) show results similar about the number of species of Eimeria diagnosed in this study.

The most common species in both the young and adult animals was $\boldsymbol{E}$. crandallis, regardless of the farming system, followed by $\boldsymbol{E}$. parva, $\boldsymbol{E}$. faurei, and E. ahsata. According to REEG et al. (2005) and CAVALCANTE et al. (2009), E. ovinoidalis may represent, on average, $70 \%$ of the oocysts that are excreted by animals between 17 and 40 days of age; this frequency decreases gradually until the oocysts of $\boldsymbol{E}$. crandallis and $\boldsymbol{E}$. parva become predominant in animals older than 80 to 100 days of age. Although the present study involved young animals, the frequency of $\boldsymbol{E}$. ovinoidalis infection was relatively low, regardless of the animal age and farming system. In another side, SILVA et al. (2007) also observed a higher frequency of $\boldsymbol{E}$. crandallis (41.4\%), followed by $\boldsymbol{E}$. parva (19.3\%).

According to DENIZ, (2008), E. crandallis

and $\boldsymbol{E}$. ovinoidalis are the species that are considered to be the most pathogenic and are mainly responsible for the development of clinical disease in young animals. However, CORDERO Del CAMPILLO \& ROJO VÁSQUEZ (2002) reported that E. bakuensis, E. ahsata, E. faurei, E. punctata, E. weybridgensis, and $\boldsymbol{E}$. parva can also be pathogenic and might trigger subclinical eimeriosis in animals, with consequent economic losses for farmers. However, in the present study, despite the observation of higher frequency of parasitism by $\boldsymbol{E}$. crandallis, no clinical signs suggestive of eimeriosis were detected in the animals.

The E. bakuensis species was found in only 1 adult animal. However, this species was the most prevalent in sheep from Kenya (MAINGI \& MUNYUA, 1994). According to FAYER (1980), factors such as the specific reproductive potential, immunity or resistance developed by the host, and the population effect may affect the prevalence rates of different Eimeria species within a herd.

VIEIRA et al. (1999) also reported higher parasitism by Eimeria in young lambs in comparison to adults. Additionally, the finding in the present study that animals raised under the intensive system were more heavily parasitized by Eimeria agrees with previous reports from LIMA (2004) and SILVA et al. (2007). However, GAULY et al. (2004) showed greater excretion of oocysts in young lambs that were reared under an extensive system in comparison to those reared under an intensive system. Nevertheless, the authors concluded that this finding was likely because the young animals reared under the extensive system did not receive a concentrate in their diet, in contrast to the other sheep, which may have led to declines in the immune statuses of the animals against this protozoan.

The decreased elimination of Eimeria oocysts in the feces of older animals is due to the agerelated development of immunity against this parasite, which is associated with previous encounters with the protozoan in question (SILVA et al., 2007). However, according to LIMA (2004), this immunity may not be absolute, and some factors related to management, such as the management of males and females during the breeding season, of females during pregnancy and / or lactation, and of agglomerated animals in small areas, could cause adult animals to once again eliminate large numbers of oocysts in the feces. 
Table 3 - Species of Eimeria, numbers of infected animals, and the mean frequencies (\%) in sheep according to the production category.

\begin{tabular}{|c|c|c|c|c|}
\hline Species & $\begin{array}{l}\text { Young and Adult (all animals) } \\
\text { Proportion (\%) }\end{array}$ & $\begin{array}{c}\text { Young (intensive) } \\
\text { Proportion (\%) }\end{array}$ & $\begin{array}{l}\text { Young (semi-intensive) } \\
\text { Proportion (\%) }\end{array}$ & $\begin{array}{c}\text { Adult (semi-intensive) } \\
\text { Proportion (\%) }\end{array}$ \\
\hline E. parva & 27.7 & 26.3 & 28.6 & 29.8 \\
\hline E. faurei & 10.1 & 8.8 & 14.3 & 10.6 \\
\hline E.crandallis & 54.7 & 53.8 & 61.9 & 53.2 \\
\hline E.ahsata & 9.5 & 7.5 & 14.3 & 10.6 \\
\hline E. granulosa & 3.4 & 2.5 & 9.5 & 2.1 \\
\hline E. intrincata & 6.8 & 6.3 & 9.5 & 6.4 \\
\hline E. ovinoidalis & 2.0 & 2.5 & 4.8 & 0.0 \\
\hline E. bakuensis & 0.7 & 0.0 & 0.0 & 2.1 \\
\hline E. ovina & 2.7 & 1.3 & 4.8 & 4.3 \\
\hline
\end{tabular}

Studies that discuss the best methods for the identification of Eimeria species have been published in recent years. According to LONG \& JOYNER, (1984), BALICKA-RAMISZ, (1999), HASSUM \& MENEZES (2005) and CAVALCANTE et al. (2012), the traditional morphological method is still the most widely used. VIEIRA et al. (2002) reported that morphometric problems with the identification of Eimeria oocysts could occur when sheep are raised together with goats because the morphological differences between the Eimeria species that infect the different animals might be imperceptible. However, this problem of Eimeria species identification is absent in the present study because the sheep grazed only along with other sheep or with cattle.

Based in the results obtained in this study, $\boldsymbol{E}$. crandallis was the most prevalent, followed by $\boldsymbol{E}$. parva and $\boldsymbol{E}$. faurei species. Higher parasitism was diagnosed in the young animals that were raised in a confinement regime $(\mathrm{P} \leq 0.05)$, and the disease found in the herd was classified as subclinical. Further studies should be conducted in this herd, to verify if the eimeriosis subclinical can cause damage especially in young animals with a high level of infection.

\section{COMMITTEE ON ETHICS}

This study was approved by the ethics committee under process 007E2/2012.

\section{REFERENCES}

AMARANTE, A.F.T.; BARBOSA, M.A. Species of coccidia ocorruring in lambs in São Paulo State, Brazil. Veterinary Parasitology, v.41, p.189-193, 1992.

BALICKA-RAMISZ, A. Studies on coccidiosis in goats in Poland. Veterinary Parasitology, v.81, p.347-349, 1999.
CAVALCANTE, A.C.R. et al. Doenças parasitárias de caprinos e ovinos. Epidemiologia e controle. Brasília: Embrapa: Informação Tecnológica, 2009. 603p.

CAVALCANTE, A.C.R. et al. Eimeria species in dairy goats in Brazil. Veterinary Parasitology, v.183, p.356-358, 2012. Available from: <http://ainfo.cnptia.embrapa.br/digital/bitstream/ item/42800/1/NT-Eimeria.pdf $>$. Accessed: Fev. 22, 2013. doi: 10.1016/j.vetpar.2011.07.043.

CORDERO del CAMPILlO, M.; ROJO VAZQUEZ, F.A. Parasitologia veterinaria. Rio de Janeiro: McGrawHillInteramericana, 2002. 123p.

DAUGSCHIES, A.; NAJDROWSKI, M. Eimeriosis in cattle: current understanding. Journal of Veterinary and Medicine, v.52, p.417-427, 2005.

DENIZ, A. Baycox ${ }^{\circledR} \mathbf{5} \%$ Toltrazuril coccidiocide for lamb. Germany, 2008. (Technical Manual - Bayer Health Care, Animal Health).

FAYER, R. Epidemiology of protozoan infection: the coccidia. Veterinary Parasitology, v.6, p.1-3, 1980.

GAULY, M. et al. Influence of production systems in lambs on the Eimeria oocysts output and weight gain. Small Ruminat Research, v.55, p.159-167, 2004. Available from: $<$ http://www.sciencedirect.com/science/article/pii/ S0921448804000537>. Accessed: Fev, 21, 2013. doi: 10.1016/j.smallrumres.2004.02.001.

GORDON, H. McL; WHITLOCK, H.V. A new technique for counting nematode eggs in sheep faeces. Commnwealth Scientific and Industrial Organization, v.12, p.50-52, 1939.

HASSUM, I.C.; MENEZES, R.C.A.A. Infecção natural por espécies do gênero Eimeria em pequenos ruminantes criados em dois municípios do estado do Rio de Janeiro. Revista Brasileira de Parasitologia Veterinária, v.14, p.95-100, 2005. Available from: $<$ http://cbpv.com.br/rbpv/documentos/1432005/c14395_100.pdf $>$. Accessed: Fev, 21, 2013.

HELLE, O. Gastrointestinal parasites in sheep on lowland pastures in eastern Norway. Acta Veterinary Scandinavica, v.34, p.1-118, 1971. 
LIMA, J.D. Coccidiose dos ruminantes domésticos. Revista Brasileira de Parasitologia Veterinária, v.13, Supl.1, p.9-13, 2004.

LONG, P.L.; JOYNER, L.P. Problems in the identification of species of Eimeria. Protozoology, v.31, p.535-541, 1984.

MAINGI, N.; MUNYUA, W.K. The prevalence and intensity of infection with Eimeria species in sheep in Nyandarua district of Kenya. Veterinary Research Communications, v.18, p.19-25, 1994.

MENEZES, R.C.C.A. et al. Prevalência das espécies do gênero Eimeria em ovinos da raça Santa Inês em um criatório na Microrregião Serrana, Estado de Rio de Janeiro: dados preliminares. Ciência Veterinária Tropical, v.4, p.268-273, 2001.

POUT, D.D. Coccidiosis of sheep: a review. Veterinary Record, v.98, p.340-341, 1976.

REEG, K.J.et al. Coccidial infections in housed lambs: oocyst excretion, antibody levels and genetic influences on the infection. Veterinary Parasitology, v.127, p.209-219, 2005. Avaliable from: <http://www. ncbi.nlm.nih.gov/pubmed/15710521>. Accessed: Fev, 21, 2013.

SILVA, N.R.S. et al. Eimerídios de ovinos no município de Porto Alegre. Arquivos da Faculdade de Medicina Veterinária da UFRGS, v.15, p.41-45, 1988 .
SILVA, T.P. et al. Dinâmica da infecção por Eimeria spp. em cordeiros da raça Santa Inês criados em sistema semi-intensivo no Norte de Minas Gerais. Arquivos Brasileiro de Medicina Veterinária e Zootecnia, v.59, p.1468-1472, 2007. Avaliable from: <http://www.scielo.br/scielo.php?script=sci_arttext\&pid $=$ S0102-09352007000600018 $>$. Accessed $:$ Fev, 21, 2013. doi: dx.doi.org/10.1590/S0102-09352007000600018.

SOMMER, C. Quantitative characterization, classification and reconstruction of oocyst shapes of Eimeria species from cattle. Parasitology, v.116, p.21-28, 1998. Avaliable from: <http://www. ncbi.nlm.nih.gov/pubmed/9481770>. Accessed : Fev, 21, 2013

UENO, H.; GONÇALVES, P.C. Manual para diagnóstico das helmintoses de ruminantes. 4.ed. Tokio: Japan International Cooperation Agency, 1998. 166p.

VERCRUYSSE, J. The coccidian of sheep and goats in Senegal. Veterinary Parasitology, v.10, p.297-306, 1982. Avaliable from: $<$ http://www.ncbi.nlm.nih.gov/pubmed/6890270>. Accessed: Fev, $21,2013$.

VIEIRA, L.S.et al. Infection with Eimeria species in hair sheep reared in Sobral, Ceará State. Revue Medicine Veterinare, v.150, p.547-550, 2009. Avaliable from: <http://www.revmedvet.com/ artdes-us.php?id=48>. Accessed : Fev,21, 2013. 